\title{
Biobutanol production from coffee silverskin
}

\author{
María Hijosa-Valsero ${ }^{1 *}$ (D), Jerson Garita-Cambronero ${ }^{1}$, Ana I. Paniagua-García ${ }^{1,2}$ and Rebeca Díez-Antolínez ${ }^{1,2}$
}

\begin{abstract}
Background: Coffee silverskin, a by-product from coffee roasting industries, was evaluated as a feedstock for biobutanol production by acetone-butanol-ethanol fermentation. This lignocellulosic biomass contained approximately $30 \%$ total carbohydrates and 30\% lignin. Coffee silverskin was subjected to autohydrolysis at $170{ }^{\circ} \mathrm{C}$ during $20 \mathrm{~min}$, with a biomass-to-solvent ratio of $20 \%$, and a subsequent enzymatic hydrolysis with commercial enzymes in order to release simple sugars. The fermentability of the hydrolysate was assessed with four solventogenic strains from the genus Clostridium. In addition, fermentation conditions were optimised via response surface methodology to improve butanol concentration in the final broth.

Results: The coffee silverskin hydrolysate contained $34.39 \pm 2.61 \mathrm{~g} / \mathrm{L}$ total sugars, which represents a sugar recovery of $34 \pm 3 \%$. It was verified that this hydrolysate was fermentable without the need of any detoxification method and that C. beijerinckii CECT 508 was the most efficient strain for butanol production, attaining final values of $4.14 \pm 0.21 \mathrm{~g} / \mathrm{L}$ acetone, $7.02 \pm 0.27 \mathrm{~g} / \mathrm{L}$ butanol and $0.25 \pm 0.01 \mathrm{~g} / \mathrm{L}$ ethanol, consuming $76.5 \pm 0.8 \%$ sugars and reaching a butanol yield of $0.269 \pm 0.008 \mathrm{~g}_{\mathrm{B}} / \mathrm{g}_{\mathrm{S}}$ under optimal conditions.
\end{abstract}

Conclusions: Coffee silverskin could be an adequate feedstock for butanol production in biorefineries. When working with complex matrices like lignocellulosic biomass, it is essential to select an adequate bacterial strain and to optimize its fermentation conditions (such as $\mathrm{pH}$, temperature or $\mathrm{CaCO}_{3}$ concentration).

Keywords: Coffee silverskin, Lignocellulosic wastes, Pretreatment, Butanol, ABE fermentation, Biorefinery

\section{Background}

In a worldwide context of high energetic costs and raw materials scarcity, it is essential to develop industrial processes with low energy requirements and using wastes as feedstocks. In recent years, much attention has been paid to n-butanol production from lignocellulosic wastes by acetone-butanol-ethanol (ABE) fermentation. Butanol has been successfully obtained from a wide range of agricultural and forestry wastes, as well as some energy crops, such as apple pomace, potato peel, brewers' spent grain, corn cobs, corn stover, corn fiber, Jerusalem artichoke, sweet sorghum bagasse, switchgrass, wheat straw and rice straw, among others [1-8]. This alcohol has numerous applications: solvent, extractant, base-product

\footnotetext{
*Correspondence: mhijv@unileon.es; hijvalma@itacyl.es

${ }^{1}$ Centro de Biocombustibles y Bioproductos, Instituto Tecnológico

Agrario de Castilla y León (ITACyL), Villarejo de Órbigo, 24358 León, Spain

Full list of author information is available at the end of the article
}

in chemical industry or fuel $[9,10]$. The advantages of butanol as a fuel, in comparison to ethanol, are its higher flash point, higher energy content, lower volatility and lower hygroscopicity; in addition, butanol can be easily mixed with gasoline at any proportion and it can be transported through existing pipelines $[9,10]$.

Coffee is one of the most consumed beverages worldwide. In 2016, the agricultural area devoted to green coffee cultivation reached 10,975,184 ha, which yielded 9,221,534 t green coffee. The main producing countries were Brazil, Vietnam, Colombia and Indonesia [11]. During the processing of coffee fruits-either by wet or dry methods-the outer skin, pulp, pectic adhesive layer and parchment are removed, whereas the green coffee beans surrounded by an attached silverskin are preserved and sent to roasting industries in consuming countries [12]. Coffee silverskin is a thin tegument obtained as a byproduct after the roasting process [13] and it constitutes about $4.2 \%(\mathrm{w} / \mathrm{w})$ of coffee beans [14]. Coffee silverskin 
contains important amounts of cellulosic and hemicellulosic fibres [13, 14], as well as interesting molecules such as caffeine and polyphenolic compounds, which makes this by-product an interesting source of cellulose [15], dietary fibres [16] and antioxidants [17, 18], and its use has also been proposed as fuel [19,20], compost [19, 20], fertilizer [20] and feedstock for amylase or ethanol production by fermentation [13, 21, 22].

In 2016 the European Union (EU-28) imported 2.95 Mt of green coffee and produced about $1.90 \mathrm{Mt}$ of roasted coffee [23]. The coffee silverskin obtained in roasting industries could be an alternative carbohydrate source to be used in butanol biorefineries, due to its continuous production throughout the year, its polysaccharide content and its availability. However, to the best of our knowledge, coffee silverskin has never been successfully employed as a feedstock for ABE fermentation. In the present work, the use of coffee silverskin as a feedstock for biobutanol production was assessed. The aims of this study were to hydrolyze cellulose and hemicellulose from coffee silverskin into simple fermentable sugars and to obtain a broth which could be directly fermentable by solventogenic Clostridium strains to produce butanol.

\section{Methods}

\section{Chemicals and reagents}

Analytical grade $\mathrm{H}_{2} \mathrm{SO}_{4}, \mathrm{HCl}$ and $\mathrm{NaOH}$ were obtained from Panreac (Castellar del Vallès, Spain). Citric acid anhydrous was purchased from Sigma-Aldrich (Steinheim, Germany). The enzyme Cellic CTec2, whose enzymatic activity was $124 \mathrm{FPU} / \mathrm{mL}$ and protein content was $176 \mathrm{mg} / \mathrm{mL}$, was provided by Novozymes (Tianjin, China).

\section{Biomass description and processing}

Dry coffee silverskin was kindly provided by Illycaffè S.p.A. (Trieste, Italy) in summer 2016. The biomass was ground in a SM100 Comfort rotary mill (Retsch GmbH, Haan, Germany) and sieved to a size of 0.5-1.0 mm.

Moisture, ash, structural carbohydrates (cellulose and hemicellulose), starch, lignin, proteins, fats and total phenolic compounds were analysed as described by HijosaValsero et al. [7]. The chemical composition of coffee silverskin can be found in Table 1 .

\section{Pretreatment of coffee silverskin Physicochemical pretreatment}

An autohydrolysis pretreatment was performed with a high-pressure 2-L reactor made of alloy Carpenter-20 (Parr Instrument Company, Moline, IL, USA). Given the total carbohydrate content in coffee silverskin (Table 1), a biomass-to-solvent ratio of $20 \%(\mathrm{w} / \mathrm{w})$ was chosen to guarantee a sufficient concentration of simple sugars in the final hydrolysate. Therefore, $80 \mathrm{~g}$ dry biomass were placed in the reactor container and $320 \mathrm{~g}$ distilled water were added. The reaction mixture was heated at a rate of about $7.6{ }^{\circ} \mathrm{C} / \mathrm{min}$ with continuous stirring, until a temperature of $170{ }^{\circ} \mathrm{C}$ was attained. Then, the reactor was kept at that temperature during $20 \mathrm{~min}$. At the end of the process, the reactor was cooled and the solid/liquid mixture was recovered.

\section{Enzymatic hydrolysis}

After the autohydrolysis, an enzymatic hydrolysis was carried out on the solid/liquid mixture obtained in the reactor. The sample was placed in a $500-\mathrm{mL}$ Erlenmeyer flask, and then $3.88 \mathrm{~g}$ citric acid dissolved in $5 \mathrm{~mL}$ water were added. The $\mathrm{pH}$ was adjusted to 5.0 with a $40 \% \mathrm{NaOH}$ solution. This made a buffer citrate of about $50 \mathrm{mM}$ and $\mathrm{pH} 5.0[24,25]$. Afterwards, $2320 \mu \mathrm{l}$ of the enzyme Cellic CTec2 (Novozymes, Tianjin, China) were added (approximately $29 \mu \mathrm{l}$ enzyme per gramme of dry coffee silverskin). The flasks were capped and placed in an orbital shaker at $50{ }^{\circ} \mathrm{C}$ and $180 \mathrm{rpm}$ during $72 \mathrm{~h}$. After enzymatic hydrolysis, the samples were filtered and prepared for chemical analyses as explained in section "Chemical analyses of hydrolysates and fermented broths", in order to quantify simple sugars and potential fermentation inhibitors. This final hydrolysate was subjected to $\mathrm{ABE}$ fermentation.

\section{Fermentation of liquid hydrolysates and strain selection} The strains Clostridium beijerinckii CECT 508 (=NCIMB 8052) (CECT, Paterna, Spain), C. beijerinckii DSM 6423, C. saccharobutylicum DSM 13864 and C. saccharoperbutylacetonicum DSM 2152 (DSMZ, Braunschweig, Germany) were assessed for the fermentation of coffee silverskin hydrolysates. Strain culture and inocula preparation for C. beijerinckii CECT 508 was performed according to Díez-Antolínez et al. [26]. For the strains $C$. beijerinckii DSM 6423, C. saccharobutylicum DSM 13864 and C. saccharoperbutylacetonicum DSM 2152, lyophilised cells were resuspended in $10 \mathrm{~mL}$ sterile medium containing $19 \mathrm{~g} / \mathrm{L}$ Reinforced Clostridial MediumRCM (Oxoid, Basingstoke, UK) and $10 \mathrm{~g} / \mathrm{L}$ glucose. This medium was incubated during $24 \mathrm{~h}$ at $35^{\circ} \mathrm{C}$ under anaerobic conditions. Then, $1.5 \mathrm{~mL}$ were transferred to a sterile cryogenic vial and $0.4 \mathrm{~mL}$ glycerol $(80 \% \mathrm{v} / \mathrm{v})$ were added. The vials were closed, shaken and stored at $-80{ }^{\circ} \mathrm{C}$ until being used. For the cellular reactivation of C. beijerinckii DSM 6423 and C. saccharobutylicum DSM 13864 , a loopful of the thawed glycerinate was spread on a Petri dish containing $38 \mathrm{~g} / \mathrm{L} \mathrm{RCM}$ and $20 \mathrm{~g} / \mathrm{L}$ agar, and 
the dish was incubated at $35{ }^{\circ} \mathrm{C}$ under anaerobic conditions until colonies were visible $(1-3 \mathrm{~mm})$. Then, a colony was transferred to $50 \mathrm{~mL}$ of sterile liquid medium $(19 \mathrm{~g} / \mathrm{L}$ RCM, $10 \mathrm{~g} / \mathrm{L}$ glucose). In the case of $C$. saccharoperbutylacetonicum DSM 2152, potato medium [27] was used instead of RCM. Afterwards, gaseous $\mathrm{N}_{2}$ was injected into the headspace of the closed bottles during $5 \mathrm{~min}$ to obtain anaerobic conditions. The bottles were incubated for $24 \mathrm{~h}$ at $35^{\circ} \mathrm{C}$ and were employed as inocula, containing an approximate bacterial density of $5 \cdot 10^{8}$ cells $/ \mathrm{mL}$.

For fermentability tests, coffee silverskin hydrolysates were filtered through a nylon mesh (30 denier) and the filtrate was centrifuged at $2480 \times g$ during $10 \mathrm{~min}$ (centrifuge Jouan CR3i, Château-Gontier, France). Afterwards, hydrolysates were supplemented with 1 or $5 \mathrm{~g} / \mathrm{L}$ yeast extract, $2.1 \mathrm{~g} / \mathrm{L} \mathrm{NH}_{4} \mathrm{Cl}, 0.5 \mathrm{~g} / \mathrm{L} \mathrm{K}_{2} \mathrm{HPO}_{4}, 0.5 \mathrm{~g} / \mathrm{L} \mathrm{KH}_{2} \mathrm{PO}_{4}$, $0.01 \mathrm{~g} / \mathrm{L} \mathrm{FeSO}_{4} \cdot 7 \mathrm{H}_{2} \mathrm{O}, 0.2 \mathrm{~g} / \mathrm{L} \quad \mathrm{MgSO}_{4} \cdot 7 \mathrm{H}_{2} \mathrm{O}, 0.5 \mathrm{~g} / \mathrm{L}$ cysteine and $5 \mathrm{~g} / \mathrm{L} \mathrm{CaCO}_{3}$, autoclaved and adjusted to pH 6.0. Two levels of yeast extract concentration were tested, as this nutrient usually has an important effect on ABE yields. Then, $1.5 \mathrm{~mL}$ of the corresponding inoculum were added to $48.5 \mathrm{~mL}$ of fermentation medium in rubber-capped bottles, where gaseous $\mathrm{N}_{2}$ was bubbled during 5 min to guarantee anaerobic conditions. Fermentation bottles were incubated at $35{ }^{\circ} \mathrm{C}$ and $100 \mathrm{rpm}$ in an Infors HT Minitron orbital shaker (Infors AG, Bottmingen, Switzerland) during $96 \mathrm{~h}$. Fermentation controls were prepared with aqueous solutions containing glucose/xylose mixtures at similar concentrations to those of hexoses/pentoses found in coffee silverskin hydrolysates, and supplemented with the abovementioned nutrients. Experiments were performed in triplicate. Bacterial density in fermentation broths was determined with a Bürker counting chamber (Paul Marienfeld GmbH \& Co. KG, Lauda-Königshofen, Germany).

\section{Optimization of fermentation conditions}

The best ABE-producing strain according to the procedure described in section "Fermentation of liquid hydrolysates and strain selection" was selected and it was subjected to an experimental design to improve butanol concentrations in the fermentation broth. To this end, a Box-Behnken design linked to the response surface methodology (RSM) was applied to determine the most adequate values for temperature, initial $\mathrm{pH}$ and $\mathrm{CaCO}_{3}$ concentration during the fermentation (three independent variables) in order to maximize butanol concentration (response variable). The experimental design consisted of 15 experimental runs including three central points. Coffee silverskin hydrolysate (supplemented with $1 \mathrm{~g} / \mathrm{L}$ yeast extract and the nutrients described in section "Fermentation of liquid hydrolysates and strain selection") was fermented under the fifteen different conditions during $96 \mathrm{~h}$,
Table 1 Chemical composition of coffee silverskin (dry mass)

\begin{tabular}{lc}
\hline Parameter & Content \\
\hline Total carbohydrates (\%) & 30.37 \\
Soluble carbohydrates (\%) & 0.40 \\
Cellulose (\%) & 10.33 \\
Hemicellulose (\%) & 9.64 \\
Starch (\%) & 7.15 \\
Lignin (\%) & 29.91 \\
Protein (\%) & 14.43 \\
Fats (\%) & 4.97 \\
Ash (\%) & 5.87 \\
Moisture (\%) & 4.81 \\
Total phenolic compounds (mg/g) & 8.0 \\
\hline
\end{tabular}

and the final butanol concentrations were measured to be employed as input for the RSM model. A response surface was calculated and the resulting equation was used to estimate the optimal temperature, initial $\mathrm{pH}$ and $\mathrm{CaCO}_{3}$ concentration values to obtain the highest amount of butanol. Afterwards, the mathematically estimated optimal points were validated by performing fermentation experiments in triplicate. More details on the experimental design can be found in Additional file 1.

\section{Chemical analyses of hydrolysates and fermented broths}

Aqueous samples of hydrolysates and fermented broths were centrifuged, filtered and analyzed according to Hijosa-Valsero et al. [7] for the quantification of sugars (cellobiose, glucose, xylose, rhamnose and arabinose), potential fermentation inhibitors (formic acid, acetic acid, levulinic acid, 5-hydroxymethylfurfural (5-HMF), furfural and total phenolic compounds) and $\mathrm{ABE}$ fermentation products (acetone, butanol, ethanol, acetic acid and butyric acid). Fermentation yields $\left(\mathrm{Y}_{\mathrm{i} / \mathrm{S}}, \mathrm{g} / \mathrm{g}\right)$ were expressed as the ratio between the metabolite (i) produced and the total sugars consumed (S). Metabolite productivity rates $\left(\mathrm{W}_{\mathrm{i}}, \mathrm{g} /(\mathrm{L} \cdot \mathrm{h})\right)$ were calculated as the ratio between the metabolite (i) expressed in concentration $(\mathrm{g} / \mathrm{L})$ and the fermentation time $(\mathrm{h})$. Sugar recovery or sugar conversion efficiency (\%) was obtained as the ratio between the mass of simple sugars in the hydrolysate and the total mass of carbohydrates in the untreated coffee silverskin (the volume of the hydrolysate was measured after filtration in order to make this calculation).

\section{Statistical analyses}

Comparisons among samples were assessed with a one-way ANOVA and Tukey's HSD test using the software Statistica 7 (StatSoft Inc., Tulsa, OK, USA). Box-Behnken RSM experimental designs were performed with the software Minitab 16 (Minitab Inc., State College, PA, USA). 


\section{Results and discussion}

\section{Coffee silverskin hydrolysis}

The initial total carbohydrate content of the studied coffee silverskin was about 30\% (Table 1), which is lower than values described by other authors, who reported cellulose contents of $18-24 \%$ [13, 14], hemicellulose contents of $13-17 \%[13,14]$ or total fibre contents of $54-62 \%$ $[12-14,16]$. Because of this, a biomass-to-solvent ratio of $20 \%$ was used during the pretreatment, in order to guarantee a sufficient amount of total carbohydrates in the hydrolysate. Table 2 shows the chemical composition of coffee silverskin hydrolysates after the autohydrolysis and after the subsequent enzymatic hydrolysis. Autohydrolysis alone only released $6.54 \mathrm{~g} / \mathrm{L}$ simple sugars, but it contributed to cellulose and hemicellulose degradation, which were partially hydrolyzed during the enzymatic treatment, thus producing a final hydrolysate with $34.39 \mathrm{~g} / \mathrm{L}$ total sugars. Sugar recovery efficiency was relatively low $(33.74 \pm 3.49 \%)$, but it can be considered successful in comparison to previous data. For instance, Niglio et al. [28] treated coffee silverskin with a combination of $\mathrm{H}_{2} \mathrm{SO}_{4}$ and ultrasounds, followed by enzymatic hydrolysis, and attained an approximate sugar recovery yield of $18 \%$ working with $3 \%$ biomass, and $16 \%$ sugar yield working with $10 \%$ biomass. Taking into account that the present work was performed with an initial biomass content of $20 \%$, and that sugar recovery yields are inversely related to biomass amounts, then autohydrolysis can be proposed as an appropriate pretreatment for coffee silverskin. Caffeine concentrations in the hydrolysates (Table 2) are consistent with reported caffeine contents in coffee silverskin [17].

The combination of autohydrolysis and enzymatic hydrolysis for lignocellulosic biomass degradation and subsequent fermentation has been explored by different authors. Buruiana et al. [29] pretreated corn stover (10\% $\mathrm{p} / \mathrm{v}$ ) with autohydrolysis at $180-223{ }^{\circ} \mathrm{C}$, followed by a treatment with $\beta$-glucosidase, obtaining a yield of $12.6 \%$ soluble sugars. The resulting broth was fermented by Saccharomyces cerevisiae CECT 1170, producing $51.6 \mathrm{~g} / \mathrm{L}$ ethanol. Amiri and Karimi [24] subjected pine and elm wood $(10 \% \mathrm{w} / \mathrm{v})$ to autohydrolysis at $180{ }^{\circ} \mathrm{C}$ during $60 \mathrm{~min}$, and then to an enzymatic hydrolysis with Celluclast $1.5 \mathrm{~L}$ (cellulase) and Novozym 188 ( $\beta$-glucosidase), releasing about $20 \%$ soluble sugars. Pine wood hydrolysate, with an initial sugar concentration of $20.8 \mathrm{~g} / \mathrm{L}$, was fermented by $C$. acetobutylicum NRRL B-591 and yielded $3.5 \mathrm{~g} / \mathrm{L}$ butanol, $2 \mathrm{~g} / \mathrm{L}$ acetone and $0.4 \mathrm{~g} / \mathrm{L}$ ethanol, whereas elm wood hydrolysate $(23.2 \mathrm{~g} / \mathrm{L}$ initial sugars) only produced $2.5 \mathrm{~g} / \mathrm{L}$ ABE. Gonçalves et al. [25] performed an autohydrolysis $\left(200{ }^{\circ} \mathrm{C}, 50 \mathrm{~min}\right)$ on green coconut shells, followed by an enzymatic treatment with Cellic CTec2 and Cellic HTec2, resulting in a sugar release of $91 \%$ from cellulose. The hydrolysates were fermented by Pichia stipitis Y7124, S. cerevisiae PE2 or Zymomonas mobilis B14023, obtaining ethanol concentrations of 7.30-8.78 g/L [yields $0.43-0.45 \mathrm{~g} / \mathrm{g}$; productivity $0.15-0.18 \mathrm{~g} /(\mathrm{L} \cdot \mathrm{h})]$.

\section{Coffee silverskin fermentation}

The four strains (CECT 508, DSM 6423, DSM 13864 and DSM 2152) were able to grow in coffee silverskin hydrolysates, as denoted by their total sugar consumption above $50 \%$ (Table 3), although there were important differences in $\mathrm{ABE}$ fermentation performance depending on the strain (Table 3). Clostridium beijerinckii CECT 508 was the most efficient strain, followed by $C$. beijerinckii DSM 6423, C. saccharoperbutylacetonicum DSM 2152 and C. saccharobutylicum DSM 13864 (Table 3). Actually, C. beijerinckii CECT 508 was statistically superior $(\mathrm{p}<0.05)$ to the other strains in terms of $\mathrm{ABE}$ production under $1 \mathrm{~g} / \mathrm{L}$ yeast extract, obtaining $3.28 \mathrm{~g} / \mathrm{L}$ acetone, $5.94 \mathrm{~g} / \mathrm{L}$ butanol and $0.28 \mathrm{~g} / \mathrm{L}$ ethanol, with a butanol yield of $0.245 \mathrm{~g} / \mathrm{g}$ and a butanol productivity of $0.062 \mathrm{~g} /$ (L.h) (Table 3), and butanol production from coffee silverskin hydrolysates by $C$. beijerinckii CECT 508 under $5 \mathrm{~g} / \mathrm{L}$ yeast extract was statistically higher $(\mathrm{p}<0.07)$ than that of the strains C. saccharobutylicum DSM 13864 and C. saccharoperbutylacetonicum DSM 2152. Regarding the role of yeast extract concentration on ABE performance, no significant differences $(\mathrm{p}<0.05)$ were observed between coffee silverskin hydrolysates containing 1 or $5 \mathrm{~g} / \mathrm{L}$ yeast extract, for any of the four strains (Table 3). Therefore, in order to reduce costs, it is preferable to add only $1 \mathrm{~g} / \mathrm{L}$ yeast extract.

The toxic effect of coffee silverskin hydrolysates on the four strains tested was visible on sugar utilization, since total sugar consumption was $93-100 \%$ for control samples and $52-79 \%$ for hydrolysates (Table 3 ). In addition, an evident negative effect on cell growth was observed for bacteria developing in coffee silverskin hydrolysate in comparison to their respective controls (Table 3). Cell density was 1.40-1.86 times higher in control samples than in hydrolysates for the strains $C$. beijerinckii CECT 508 and C. saccharobutylicum DSM 13864, and 2.68-4.78 times higher for C. beijerinckii DSM 6423 and C. saccharoperbutylacetonicum DSM 2152. The strains C. beijerinckii DSM 6423, C. saccharobutylicum DSM 13864 and C. saccharoperbutylacetonicum DSM 2152 suffered a significant decrease in butanol production when comparing coffee silverskin hydrolysates and control fermentations, regardless of their initial yeast extract concentration $(\mathrm{p}<0.05)$. On the contrary, the strain $C$. beijerinckii CECT 508 produced $5.94 \mathrm{~g} / \mathrm{L}$ butanol from coffee silverskin hydrolysates under $1 \mathrm{~g} / \mathrm{L}$ yeast extract, a value which was not significantly different $(\mathrm{p}<0.05)$ 
Table 2 Composition of coffee silverskin hydrolysates after each pretreatment step, expressed in $\mathrm{g} / \mathrm{L}$

\begin{tabular}{lcc}
\hline & Autohydrolysis & $\begin{array}{l}\text { Autohydrolysis +enzymatic } \\
\text { hydrolysis }\end{array}$ \\
\hline Cellobiose & $0.56 \pm 0.25$ & $0.62 \pm 0.07$ \\
Glucose & $0.51 \pm 0.10$ & $21.83 \pm 0.81$ \\
Xylose & $1.73 \pm 0.28$ & $9.44 \pm 1.71$ \\
Rhamnose & $2.65 \pm 0.33$ & $1.01 \pm 1.00$ \\
Arabinose & $1.11 \pm 0.25$ & $1.49 \pm 0.56$ \\
Total sugars & $6.54 \pm 0.80$ & $34.39 \pm 2.61$ \\
Formic acid & $1.76 \pm 0.26$ & $1.64 \pm 0.20$ \\
Acetic acid & $1.32 \pm 0.14$ & $1.94 \pm 0.05$ \\
Levulinic acid & $0.00 \pm 0.00$ & $0.00 \pm 0.00$ \\
5-HMF & $0.09 \pm 0.02$ & $0.07 \pm 0.01$ \\
Furfural & $0.08 \pm 0.05$ & $0.09 \pm 0.01$ \\
Phenolic compounds & $1.51 \pm 0.00$ & $1.52 \pm 0.03$ \\
Caffeine & $0.91 \pm 0.07$ & $0.82 \pm 0.04$
\end{tabular}

Means and standard deviations are provided. Autohydrolysis conditions: $170^{\circ} \mathrm{C}$, $20 \mathrm{~min}, 20 \%$ solid biomass. Xylose concentration is in fact a sum of xylose, galactose and mannose concentrations

from the concentration of $6.55 \mathrm{~g} / \mathrm{L}$ obtained in its control sample (Table 3). This could indicate that this particular strain is more tolerant to the possible inhibitors found in the hydrolysates (Table 2). It was experimentally determined that $C$. beijerinckii CECT 508 did not consume caffeine during the fermentation of these hydrolysates (caffeine concentration in the broth after $96 \mathrm{~h}$ of fermentation was $0.85 \pm 0.01 \mathrm{~g} / \mathrm{L}$ ). Some bacteria have evolved to metabolize caffeine, due to the frequent presence of this plant-origin compound in the environment [30]. On the other hand, several studies report growth inhibition or metabolic interference in certain bacterial groups caused by caffeine [31,32], as well as metabolic changes such as the stimulation of sporulation or the inhibition of macromolecular synthesis in other Clostridium species [33, 34]. Moreover, the concentration of phenolic compounds did not vary during the fermentation (final concentration $1.51 \pm 0.01 \mathrm{~g} / \mathrm{L}$ ), thus indicating that $C$. beijerinckii CECT 508 did not metabolize this type of inhibitory substances. Therefore, further research in this matter, regarding solventogenic Clostridia, could be useful in order to improve butanol generation in the three less productive strains found in the present work.

\section{Optimization of fermentation conditions with the selected strain}

In spite of the relatively low initial sugar concentration $(34 \mathrm{~g} / \mathrm{L})$, coffee silverskin hydrolysate was successfully fermented into $5.94 \pm 0.29 \mathrm{~g} / \mathrm{L}$ butanol by one of the strains (C. beijerinckii CECT 508). In order to check the possibility of improving this butanol concentration when fermenting coffee silverskin hydrolysates with $C$. beijerinckii CECT 508, the most appropriate values for temperature, initial $\mathrm{pH}$ and $\mathrm{CaCO}_{3}$ concentration during fermentation were optimized via RSM. The fifteen fermentation experiments produced variable butanol amounts, ranging from 0 to $7.42 \mathrm{~g} / \mathrm{L}$ (Additional file 1: Table S2). These data were used to build a mathematical model (Fig. 1) which explained $88.63 \%$ of the variation, but its predicted $\mathrm{R}$-square value of $0 \%$ indicated that the model was overfit (Additional file 1: Table S6).

The equation of the model (Additional file 1: Table S6) was used to calculate the optimal values of temperature, initial $\mathrm{pH}$ and $\mathrm{CaCO}_{3}$ concentration which would yield the highest butanol concentration. The optimization output indicated that the best fermentation parameters would be $33.9{ }^{\circ} \mathrm{C}$, initial $\mathrm{pH} 5.59$ and $7.55 \mathrm{~g} / \mathrm{L} \mathrm{CaCO}_{3}$, and the estimated butanol concentration under those conditions would be $6.30 \mathrm{~g} / \mathrm{L}$.

The model was validated experimentally by fermenting coffee hydrolysates under the optimal conditions $\left(33.9{ }^{\circ} \mathrm{C}, \mathrm{pH} 5.59\right.$ and $\left.7.55 \mathrm{~g} / \mathrm{L} \mathrm{CaCO}_{3}\right)$ in triplicate. This validation gave a result of $7.02 \pm 0.27 \mathrm{~g} / \mathrm{L}$ butanol (Table 4$)$, which is significantly higher $(\mathrm{p}<0.05)$ than the previously recorded value of $5.94 \pm 0.29 \mathrm{~g} / \mathrm{L}$ butanol before optimization (section "Coffee silverskin fermentation"). In spite of the real improvement obtained, it must be noted that the RSM model was not very accurate to estimate butanol production $(6.30 \mathrm{~g} / \mathrm{L}$ estimated vs. $7.02 \mathrm{~g} / \mathrm{L}$ experimental). This could be due to the abovementioned overfitting. The reasons underlying this fact may be related to the variable composition of coffee silverskin hydrolysates depending on the batch (Table 2) or to the changeable responses of bacterial spore batches used to prepare the inocula on different days.

Regarding the calculated values for the maximum butanol production $\left(33.9^{\circ} \mathrm{C}\right.$, initial $\mathrm{pH} 5.59$ and $7.55 \mathrm{~g} / \mathrm{L}$ $\mathrm{CaCO}_{3}$ ), all of them are within the normal ranges for conventional ABE fermentations. Optimal fermentation temperatures depend on the nature of the feedstock, and they can lie between 29 and $39^{\circ} \mathrm{C}$ [35]. Good levels of solvent production have been obtained for $\mathrm{pH}$ ranges of 5.0-6.5 [35], but $\mathrm{pH}$-dependence varies from strain to strain [36]. When $\mathrm{CaCO}_{3}$ is used in fermentation broths for $\mathrm{pH}$ control, its concentration is about $5 \mathrm{~g} / \mathrm{L}[26,37]$. In a recent review, Ujor et al. [38] discussed that $\mathrm{CaCO}_{3}$ does not only work as a buffer during $\mathrm{ABE}$ fermentations, but it could also favor the concomitant use of glucose and xylose, enhance butanol tolerance and reduce the toxic effects of lignocellulosic biomass hydrolysates.

To the best of our knowledge, coffee by-products had never been transformed into biobutanol yielding such high titers. The concentration obtained under optimal 


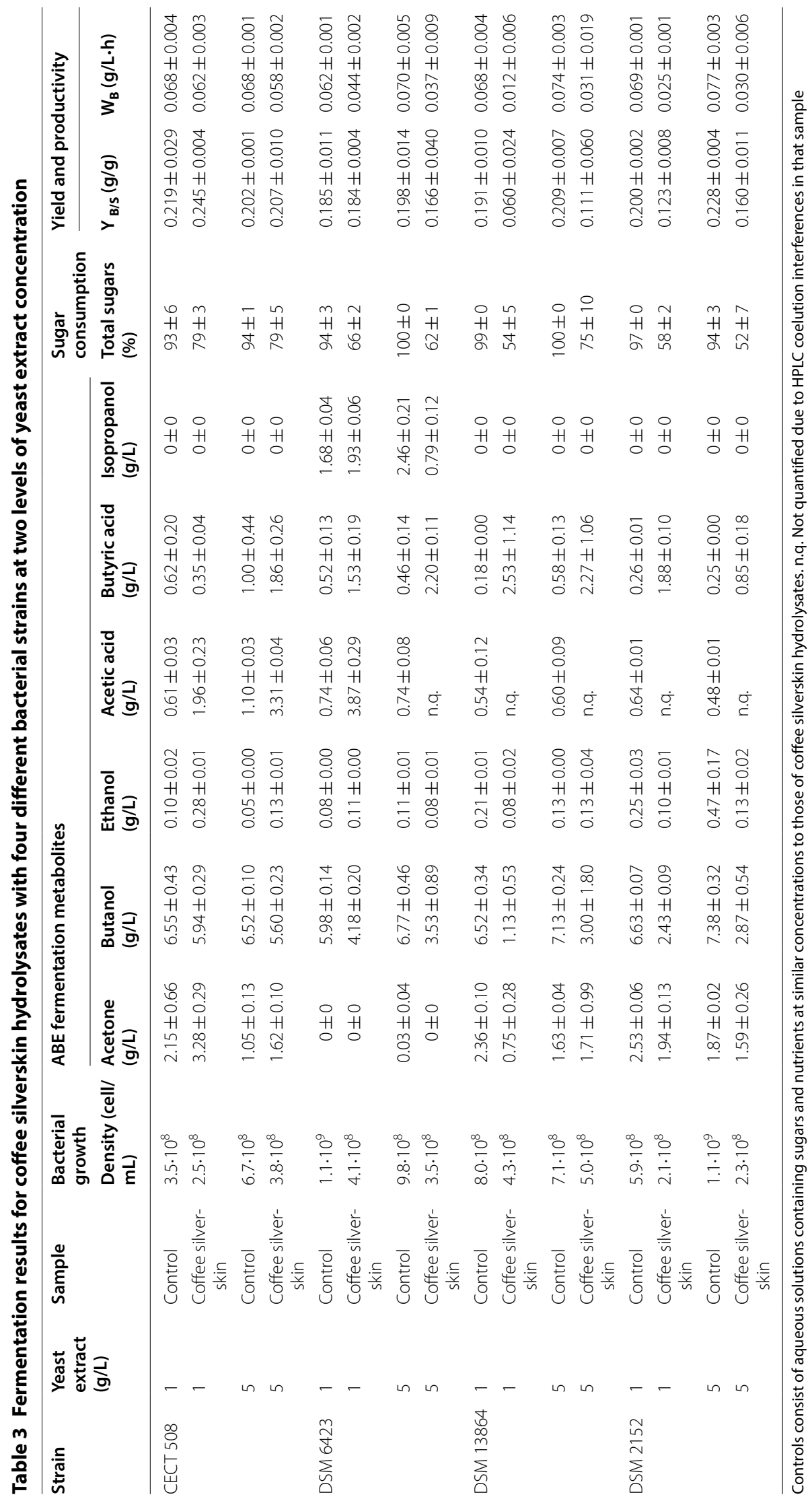


conditions with coffee silverskin hydrolysates $(7.02 \mathrm{~g} / \mathrm{L}$ butanol) can be considered in the medium-high range of the values that are usually obtained from lignocellulosic biomass [39-42]. For instance, other agricultural or food wastes have been proven to be suitable feedstocks for the production of this solvent, like corn stover $(8.98 \mathrm{~g} / \mathrm{L}$ butanol) [43], apple pomace (9.11 g/L butanol) [7], grape marc (6 g/L butanol) [44], or wheat straw $(12.0 \mathrm{~g} / \mathrm{L}$ butanol) [45]. In addition, there is still room for a further optimization of the global process to obtain butanol from coffee silverskin. For instance, the adjustment of enzymatic hydrolysis and the concentration of its buffering solution is known to have an important effect on butanol generation $[46,47]$.

The possibility of directly fermenting coffee silverskin without the need of expensive detoxification steps makes this biomass attractive for biorefineries. In addition, coffee silverskin may be mixed with other food or agricultural wastes with a higher carbohydrate composition, thus enabling the production of hydrolysates richer in sugar contents, which could lead to higher butanol concentrations in the fermentation broth. This would significantly reduce butanol separation and purification costs at biorefineries with conventional or alternative methods such as gas stripping, pervaporation, adsorption, liquid-liquid extraction or combined techniques [48]. For instance, in the case of gas stripping it is advisable that butanol is present in the broth at concentrations higher than $8 \mathrm{~g} / \mathrm{L}$ to save energy $[46,49,50]$.

\section{Conclusions}

Coffee silverskin could be an adequate feedstock for $\mathrm{ABE}$ fermentation in biorefineries. Its physicochemical pretreatment by autohydrolysis is technically easy and environmentally friendly, because it does not require any reagent but water. Another advantage of the developed treatment is the absence of detoxification steps, which simplifies the process and makes it more economically feasible. However, further research is still needed to implement butanol production from

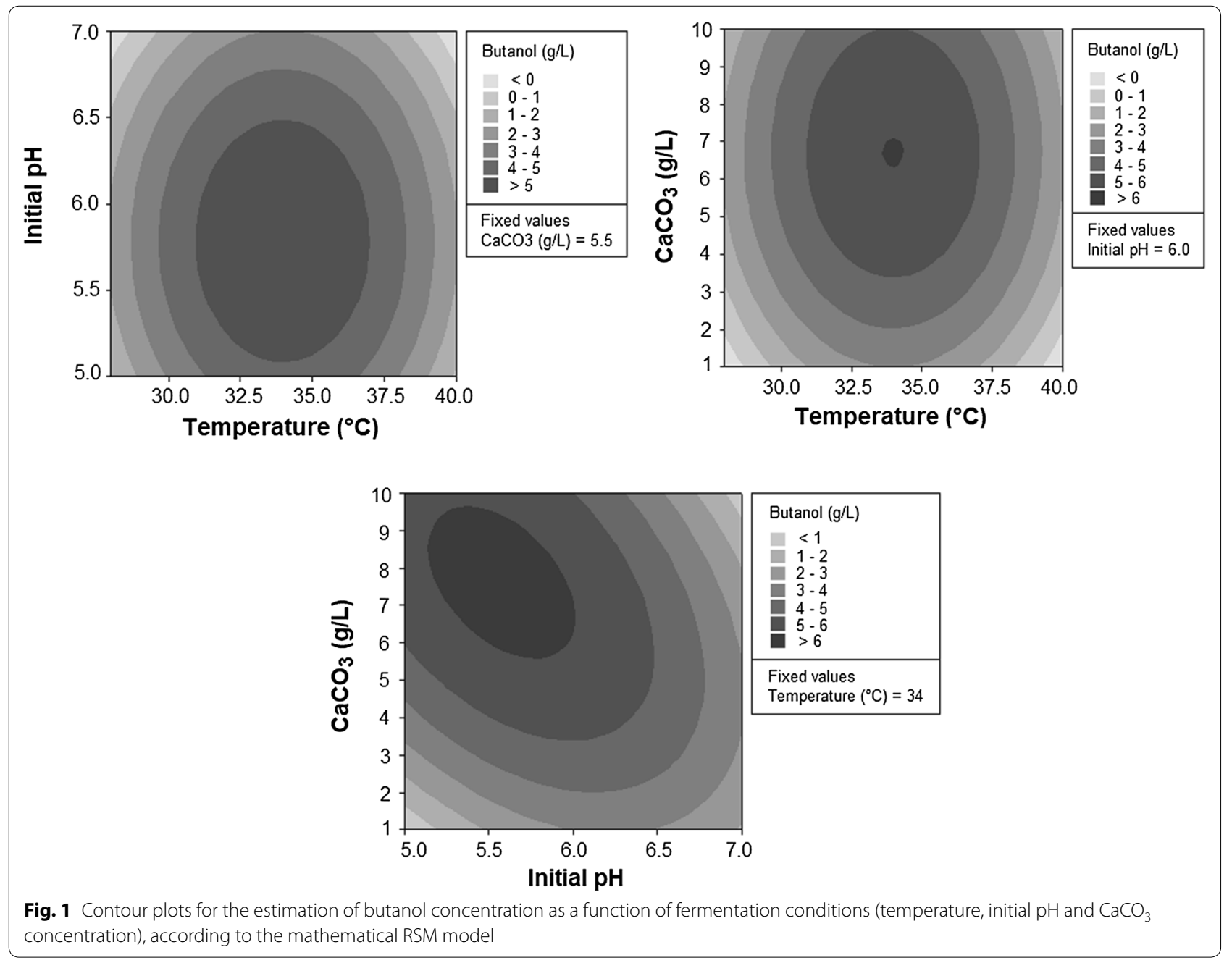


Table 4 Fermentation of coffee silverskin hydrolysates with C. beijerinckii CECT 508 under optimal conditions $\left(33.9{ }^{\circ} \mathrm{C}\right.$, pH 5.59 and $7.55 \mathrm{~g} / \mathrm{L} \mathrm{CaCO}_{3}$ ) after $96 \mathrm{~h}$

\begin{tabular}{ll}
\hline ABE fermentation metabolites & \\
Acetone $(\mathrm{g} / \mathrm{L})$ & $4.14 \pm 0.21$ \\
Butanol $(\mathrm{g} / \mathrm{L})$ & $7.02 \pm 0.27$ \\
Ethanol $(\mathrm{g} / \mathrm{L})$ & $0.25 \pm 0.01$ \\
Acetic acid $(\mathrm{g} / \mathrm{L})$ & $2.42 \pm 0.05$ \\
Butyric acid $(\mathrm{g} / \mathrm{L})$ & $0.57 \pm 0.14$ \\
Sugar consumption & \\
Total sugars (\%) & $76.5 \pm 0.8$ \\
Yield and productivity & \\
$\mathrm{Y}_{B / S}(\mathrm{~g} / \mathrm{g})$ & $0.269 \pm 0.008$ \\
$W_{B}[\mathrm{~g} /(\mathrm{L} \cdot \mathrm{h})]$ & $0.073 \pm 0.003$ \\
\hline
\end{tabular}

lignocellulosic wastes at industrial scale, especially in order to achieve higher butanol concentrations during $\mathrm{ABE}$ fermentation and to improve butanol separation and purification technologies.

\section{Additional file}

Additional file 1. Details on statistical processes for optimizing the fermentation are supplied as additional information.

\section{Abbreviations}

ABE: acetone-butanol-ethanol; RSM: response surface methodology.

\section{Authors' contributions}

$\mathrm{MH}-\mathrm{V}$ and RD-A conceived and designed the experiments. AIP-G acquired the data. All authors analysed and interpreted the data. MH-V and JG-C wrote the manuscript with contributions from all authors. All authors read and approved the final manuscript.

\section{Author details}

${ }^{1}$ Centro de Biocombustibles y Bioproductos, Instituto Tecnológico Agrario de Castilla y León (ITACyL), Villarejo de Órbigo, 24358 León, Spain. ${ }^{2}$ Instituto de Recursos Naturales (IRENA), Universidad de León, Avenida de Portugal 42, 24071 León, Spain.

\section{Acknowledgements}

The authors thank Novozymes China for kindly providing samples of their enzymes. The authors are grateful to Illycaffè S.p.A. (Trieste, Italy) for generously supplying coffee silverskin. Authors thank R. Antón del Río, N. del Castillo Ferreras and G. Sarmiento Martínez for their technical help. We would like to thank Prof. Luiz P. Ramos from Universidade Federal do Paraná for his fruitful comments to enrich the manuscript.

\section{Competing interests}

The authors declare that they have no competing interests.

\section{Availability of data and materials}

All data generated or analysed during this study are included in this published article and its additional file.

\section{Consent for publication}

Not applicable.
Ethics approval and consent to participate Not applicable.

\section{Funding}

The present work has been performed as part of the H2020-LCE-2015 Waste2Fuels project (Sustainable production of next generation biofuels from waste streams - Waste2Fuels. GA - 654623), funded by the European Union's Horizon 2020 Research and Innovation Programme. MH-V is supported by a postdoctoral contract (DOC-INIA, Grant Number DOC 2013-010) funded by the Spanish National Institute for Agricultural and Food Research and Technology (INIA) and the European Social Fund.

\section{Publisher's Note}

Springer Nature remains neutral with regard to jurisdictional claims in published maps and institutional affiliations.

Received: 21 July 2018 Accepted: 24 September 2018

Published online: 27 September 2018

\section{References}

1. Gu Y, Jiang Y, Yang S, Jiang W. Utilization of economical substrate-derived carbohydrates by solventogenic Clostridia: pathway dissection, regulation and engineering. Curr Opin Biotechnol. 2014;29:124-31. https://doi. org/10.1016/j.copbio.2014.04.004.

2. Jurgens G, Survase S, Berezina O, Sklavounos E, Linnekoski J, Kurkijärvi A, et al. Butanol production from lignocellulosics. Biotechnol Lett. 2012;34:1415-34. https://doi.org/10.1007/s10529-012-0926-3.

3. Menon V, Rao M. Trends in bioconversion of lignocellulose: biofuels, platform chemicals and biorefinery concept. Prog Energy Combust Sci. 2012;38:522-50. https://doi.org/10.1016/j.pecs.2012.02.002

4. Xue C, Zhao X-Q, Liu C-G, Chen L-J, Bai F-W. Prospective and development of butanol as an advanced biofuel. Biotechnol Adv. 2013;31:157584. https://doi.org/10.1016/j.biotechadv.2013.08.004.

5. Amiri H, Karimi K. Pretreatment and hydrolysis of lignocellulosic wastes for butanol production: challenges and perspectives. Bioresour Technol. 2018. https://doi.org/10.1016/j.biortech.2018.08.117.

6. Gottumukkala LD, Haigh K, Görgens J. Trends and advances in conversion of lignocellulosic biomass to biobutanol: microbes, bioprocesses and industrial viability. Renew Sustain Energy Rev. 2017;76:963-73. https://doi. org/10.1016/j.rser.2017.03.030.

7. Hijosa-Valsero M, Paniagua-García Al, Díez-Antolínez R. Biobutanol production from apple pomace: the importance of pretreatment methods on the hydrolysis of lignocellulosic agro-food wastes. Appl Microbiol Biotechnol. 2017;101:8041-52. https://doi.org/10.1007/s00253-017-8522-z.

8. Hijosa-Valsero M, Paniagua-García Al, Díez-Antolínez R. Industrial potato peel as a feedstock for biobutanol production. New Biotechnol. 2018;46:54-60. https://doi.org/10.1016/j.nbt.2018.07.002.

9. García V, Päkkilä J, Ojamo H, Muurinen E, Keiski RL. Challenges in biobutanol production: how to improve the efficiency? Renew Sustain Energy Rev. 2011;15:964-80. https://doi.org/10.1016/j.rser.2010.11.008.

10. Zverlov WV, Berezina O, Velikodvorskaya GA, Schwarz WH. Bacterial acetone and butanol production by industrial fermentation in the Soviet Union: use of hydrolyzed agricultural waste for biorefinery. Appl Microbio Biotechnol. 2006;71:587-97. https://doi.org/10.1007/s00253-006-0445-z.

11. FAOSTAT: Data. Production. Crops. http://www.fao.org/faostat/en/\#data. 2016. Accessed 21 Feb 2018.

12. Narita $Y$, Inouye K. Review on utilization and composition of coffee silverskin. Food Res Int. 2014;61:16-22. https://doi.org/10.1016/j.foodr es.2014.01.023.

13. Mussatto SI, Machado EMS, Martins S, Teixeira JA. Production, composition, and application of coffee and its industrial residues. Food Bioprocess Technol. 2011;4:661-72. https://doi.org/10.1007/s11947-011-0565-z.

14. Ballesteros LF, Teixeira JA, Mussatto SI. Chemical, functional, and structural properties of spent coffee grounds and coffee silverskin. Food Bioprocess Technol. 2014;7:3493-503. https://doi.org/10.1007/s11947-014-1349-z.

15. Toschi TG, Cardenia V, Bonaga G, Mandrioli M, Rodriguez-Estrada MT. Coffee silverskin: characterization, possible uses, and safety aspects. J Agric Food Chem. 2014;62:10836-44. https://doi.org/10.1021/jf503200z. 
16. Pourfarzad A, Mahdavian-Mehr H, Sedaghat N. Coffee silverskin as a source of dietary fiber in bread-making: optimization of chemical treatment using response surface methodology. LWT-Food Sci Technol. 2013;50:599-606. https://doi.org/10.1016/j.Iwt.2012.08.001.

17. Bresciani L, Calani L, Bruni R, Brighenti F, Del Rio D. Phenolic composition, caffeine content and antioxidant capacity of coffee silverskin. Food Res Int. 2014:61:196-201. https://doi.org/10.1016/j.foodres.2013.10.047.

18. Narita $Y$, Inouye K. High antioxidant activity of coffee silverskin extracts obtained by the treatment of coffee silverskin with subcritical water. Food Chem. 2012;135:943-9. https://doi.org/10.1016/j.foodchem.2012.05.078

19. Esquivel $P$, Jiménez VM. Functional properties of coffee and coffee byproducts. Food Res Int. 2012;46:488-95. https://doi.org/10.1016/j.foodr es.2011.05.028.

20. Machado EMS, Rodriguez-Jasso RM, Teixeira JA, Mussatto SI. Growth of fungal strains on coffee industry residues with removal of polyphenolic compounds. Biochem Eng J. 2012;60:87-90. https://doi.org/10.1016/j. bej.2011.10.007.

21. Mussatto SI, Machado EMS, Carneiro LM, Teixeira JA. Sugars metabolism and ethanol production by different yeast strains from coffee industry wastes hydrolysates. Appl Energy. 2012;92:763-8. https://doi. org/10.1016/j.apenergy.2011.08.020.

22. Murthy PS, Naidu MM, Srinivas P. Production of a-amylase under solidstate fermentation utilizing coffee waste. J Chem Technol Biotechnol. 2009;84:1246-9. https://doi.org/10.1002/jctb.2142.

23. European Coffee Federation: European Coffee Report 2016/17. https ://www.ecf-coffee.org/publications/european-coffee-report. 2017. Accessed 20 Feb 2018.

24. Amiri H, Karimi K. Autohydrolysis: a promising pretreatment for the improvement of acetone, butanol, and ethanol production from woody materials. Chem Eng Sci. 2015;137:722-9. https://doi.org/10.1016/j. ces.2015.07.020

25. Gonçalves FA, Ruiz HA, dos Santos ES, Teixeira JA, de Macedo GR. Bioethanol production from coconuts and cactus pretreated by autohydrolysis. Ind Crop Prod. 2015;77:1-12. https://doi.org/10.1016/j.inder op.2015.06.041.

26. Díez-Antolínez R, Hijosa-Valsero M, Paniagua-García Al, Gómez X. Effect of nutrient supplementation on biobutanol production from cheese whey by ABE (acetone-butanol-ethanol) fermentation. Chem Eng Trans. 2016:49:217-22. https://doi.org/10.3303/CET1649037.

27. Yerushalmi L, Volesky B. Culture conditions for growth and solvent biosynthesis by a modified Clostridium acetobutylicum. Appl Microbiol Biotechnol. 1987;25:513-20. https://doi.org/10.1007/BF00252009.

28. Niglio S, Procentese A, Russo ME, Sannia G, Marzocchella A. Ultrasoundassisted dilute acid pretreatment of coffee silverskin for biorefinery applications. Chem Eng Trans. 2017;57:109-14. https://doi.org/10.3303/ CET1757019.

29. Buruiana CT, Vizireanu C, Garrote G, Parajó JC. Optimization of corn stover biorefinery for coproduction of oligomers and second generation bioethanol using non-isothermal autohydrolysis. Ind Crop Prod. 2014;54:32-9. https://doi.org/10.1016/j.indcrop.2014.01.003.

30. Summers RM, Gopishetty S, Mohanty SK, Subramanian M. New genetic insights to consider coffee waste as feedstock for fuel, feed, and chemicals. Cent Eur J Chem. 2014;12:1271-9. https://doi.org/10.2478/s1153 2-014-0550-2.

31. Almeida AAP, Farah A, Silva DAM, Nunan EA, Glória MBA. Antibacterial activity of coffee extracts and selected coffee chemical compounds against enterobacteria. J Agr Food Chem. 2006;54:8738-43. https://doi. org/10.1021/jf0617317.

32. Norizan SNM, Yin W-F, Chan K-G. Caffeine as a potential quorum sensing inhibitor. Sensors. 2013;13:5117-29. https://doi.org/10.3390/s130405117.

33. Juneja V, Call J, Miller A. Evaluation of methylxanthines and related compounds to enhance Clostridium perfringens sporulation using a modified Duncan and Strong medium. J Rapid Methods Autom Microbiol. 1993;2:203-18. https://doi.org/10.1111/j.1745-4581.1993.tb00290.x.

34. Labbe RG, Nolan LL. Inhibition of macromolecular synthesis by caffeine in Clostridium perfringens. Can J Microbiol. 1987;33:589-92. https://doi. org/10.1139/m87-102
35. Jones DT, Woods DR. Acetone-butanol fermentation revisited. Microbiol Rev. 1986;50(4):484-524.

36. Chen J-S, Zidwick MJ, Rogers P. Organic acid and solvent production: Butanol, acetone, and isopropanol; 1,3- and 1,2-propanediol production; and 2,3-butanediol production. In: Rosenberg E, DeLong EF, Lory S, Stackebrandt E, Thompson F, editors. The prokaryotes-applied bacteriology and biotechnology. Berlin: Springer-Verlag; 2013. p. 77-134. https://doi. org/10.1007/978-3-642-31331-8_386.

37. Marchal R, Blanchet D, Vandecasteele JP. Industrial optimization of acetone-butanol fermentation: a study of the utilization of Jerusalem artichokes. Appl Microbiol Biotechnol. 1985;23:92-8. https://doi. org/10.1007/BF00938959.

38. Ujor V, Okonkwo C, Ezeji TC. Unorthodox methods for enhancing solvent production in solventogenic Clostridium species. Appl Microbiol Biotechnol. 2016;100:1089-99. https://doi.org/10.1007/s00253-015-7166-0.

39. Salehi Jouzani G, Taherzadeh MJ. Advances in consolidated bioprocessing systems for bioethanol and butanol production from biomass: a comprehensive review. Biofuel Res J. 2015;5:152-95. https://doi.org/10.18331/ BRJ2015.2.1.4.

40. Jiang Y, Liu J, Jiang W, Yang Y, Yang S. Current status and prospects of industrial bio-production of $\mathrm{n}$-butanol in China. Biotechnol Adv. 2015;33:1493-501. https://doi.org/10.1016/j.biotechadv.2014.10.007.

41. Zheng J, Tashiro Y, Wang Q, Sonomoto K. Recent advances to improve fermentative butanol production: genetic engineering and fermentation technology. J Biosci Bioeng. 2015;119:1-9. https://doi.org/10.1016/j.jbios c.2014.05.023.

42. Kumari D, Singh R. Pretreatment of lignocellulosic wastes for biofuel production: a critical review. Renew Sustain Energy Rev. 2018;90:877-91. https://doi.org/10.1016/j.rser.2018.03.111.

43. Qureshi N, Singh V, Liu S, Ezeji TC, Saha BC, Cotta MA. Process integration for simultaneous saccharification and fermentation, and recovery (SSFR): production of butanol from corn stover using Clostridium beijerinckii P260. Bioresour Technol. 2014;154:222-8. https://doi.org/10.1016/j.biort ech.2013.11.080.

44. Law L. Production of biobutanol from white grape pomace by Clostridium saccharobutylicum using submerged fermentation. Master dissertation. Auckland University of Technology. http://hdl.handle.net/10292/1017. 2010. Accessed 20 Feb 2018.

45. Qureshi N, Saha BC, Cotta MA. Butanol production from wheat straw hydrolysate using Clostridium beijerinckii. Bioprocess Biosyst Eng. 2007;30:419-27. https://doi.org/10.1007/s00449-007-0137-9.

46. Xue $C$, Wang Z, Wang S, Zhang X, Chen L, Mu Y, Bai F. The vital role of citrate buffer in acetone-butanol-ethanol (ABE) fermentation using corn stover and high-efficient product recovery by vapor stripping-vapor permeation (VSVP) process. Biotechnol Biofuels. 2016;9:146. https://doi. org/10.1186/s13068-016-0566-2.

47. Xue C, Zhang X, Wang J, Xiao M, Chen L, Bai F. The advanced strategy for enhancing biobutanol production and high-efficient product recovery with reduced wastewater generation. Biotechnol Biofuels. 2017;10:148. https://doi.org/10.1186/s13068-017-0836-7.

48. Xue C, Zhao J, Chen L, Yang S-T, Bai F. Recent advances and state-of-theart strategies in strain and process engineering for biobutanol production by Clostridium acetobutylicum. Biotechnol Adv. 2017:35:310-22. https ://doi.org/10.1016/j.biotechadv.2017.01.007.

49. Chen Y, Ren H, Liu D, Zhao T, Shi X, Cheng H, et al. Enhancement of n-butanol production by in situ butanol removal using permeating-heating-gas stripping in acetone-butanol-ethanol fermentation. Bioresour Technol. 2014;164:276-84. https://doi.org/10.1016/j.biortech.2014.04.107.

50. Díez-Antolínez R, Hijosa-Valsero M, Paniagua Al, Gómez X. In situ twostage gas stripping for the recovery of butanol from acetone-butanolethanol (ABE) fermentation broths. Chem Eng Trans. 2018;64:37-42. https ://doi.org/10.3303/CET1864007. 